\title{
EFFECTS OF 5-HYDROXYTRYPTAMINE ON FERTILITY AND LUTEAL DEVELOPMENT FOLLOWING INTRAVAGINAL ADMINISTRATION IN THE RAT
}

\author{
K. E. KENDLE
}

School of Pharmacy, Robert Gordon's Institute, Schoolhill, Aberdeen AB9 1FR

(Received 26th October 1974)

\begin{abstract}
Summary. Intravaginal administration of $5 \mathrm{HT}$ was effective in terminating pregnancy when given after implantation in the rat, provided that the tampon was allowed to remain in the vagina for $4 \mathrm{hr}$ or more. Complete antifertility efficacy was associated with a prevention or reversal of the increase in ovarian weight, which occurs in untreated rats between Days 12 and 17 of pregnancy, and correlates with enlargement of the CL. Data from hysterectomized, ovariectomized and progesteroneimplanted rats indicated that the effect on CL was not a cause of the antifertility effect. Intravaginal administration of $5 \mathrm{HT}$ was found to lead to general systemic effects.
\end{abstract}

\section{INTRODUGTION}

The antifertility effects of 5-hydroxytryptamine (5HT), following systemic administration at or after the time of implantation in rodents, have been recognized for many years (Lindsay, Poulson \& Robson, 1963; Marley, 1969). Studies on the mechanism of action have indicated that the antifertility effects are due to reduced uterine blood flow (Marley, Robson \& Sullivan, 1967; Marley, 1974).

The present investigation was undertaken to determine whether 5HT had antifertility activity following local vaginal application in the rat, whether effects by this route were general or specific to the reproductive system and whether effects on the CL were the cause or effect of antifertility activity.

\section{MATERIALS AND METHODS}

\section{General}

Rats (S.P.F. derived) of the Porton strain were housed at a temperature of $72^{\circ} \mathrm{F} \pm 2^{\circ}$ with artificial illumination from 08.00 hours to 20.00 hours daily. Free access to FFG/LAC diet and tap water was allowed.

Mature females were caged with males of proven fertility and examined daily for evidence of successful mating, indicated by the presence of spermatozoa in the vaginal lavage. The day on which spermatozoa were found was designated Day 1 of pregnancy. 
The 5HT was used in the form of creatinine sulphate, the weights quoted being the amounts of the salt. The drug was administered by the intravaginal route on cylindrical foam-rubber tampons $8 \mathrm{~mm}$ in diameter and $10 \mathrm{~mm}$ in length. A solution of $5 \mathrm{HT}$ containing the required dose in $1 \mathrm{ml}$ distilled water was used to impregnate each tampon. These were subsequently allowed to dry in air at room temperature before insertion. Intravaginal insertion was carried out with the aid of a small glass speculum.

The amounts of $5 \mathrm{HT}$ absorbed in $4 \mathrm{hr}$ were estimated by withdrawing the tampons and extracting the $5 \mathrm{HT}$ remaining using $0.1 \mathrm{~N}-\mathrm{HCl}$. The solutions were then assayed with a Baird Atomic spectrofluorimeter at wavelengths of Ex 320 and $\mathrm{Em} 660 \mathrm{~nm}$. A calibration curve was constructed using known amounts of 5HT extracted from tampons, thus making automatic correction for any extraction losses.

Implants, $\frac{1}{4}$ in. diameter and containing approximately $25 \mathrm{mg}$ progesterone, were formed by cold compression of the pure substance. Subcutaneous administration of the implants was carried out under ether anaesthesia.

Animals were killed by cervical dislocation on Day 15 of pregnancy, except when otherwise stated. The contents of their uteri were examined and the numbers of live and resorbing fetuses were determined. The number of live fetuses was then expressed as a \% of the total number recorded. The ovaries were removed and weighed to the nearest $0.1 \mathrm{mg}$ on an electric balance. The mean ovarian weights were calculated and the significance of difference of means was examined by Student's $t$ test.

Operative procedures were carried out under light ether anaesthesia. Instruments and materials were sterilized before use and kept in a solution of $1 \%$ cetyltrimethylammonium bromide plus $0.1 \%$ chlorhexidine gluconate in $70 \%$ ethanol. This solution was also used for preparation of the skin before incision. Internal ligatures were of cotton, peritoneal sutures of silk (Abrasilk 3/0) and skin closure was by means of Michels double suture clips.

\section{Antifertility activity of $5 H T$}

Pregnant rats in one group were given $10 \mathrm{mg} 5 \mathrm{HT}$ intravaginally on Day 4 of pregnancy, while those in a similar group were dosed on Day 5 and others in further groups were dosed on Days 6, 7 or 8 . A further fifteen rats (three groups of five) were given $5 \mathrm{mg} 5 \mathrm{HT}$ on Days 6,7 or 8 . Control rats were given blank tampons.

The animals were killed on Day 15 of pregnancy and the numbers of live and resorbing fetuses were determined.

The minimum period of exposure necessary to terminate pregnancy was determined by inserting tampons containing $10 \mathrm{mg} 5 \mathrm{HT}$ on Day 6 and withdrawing them after $1,2,4,8,16$ and $32 \mathrm{hr}$ from rats in Groups 1 to 6, respectively.

\section{Mechanism of antifertility activity}

Ten rats forming one group were given $10 \mathrm{mg}$ 5HT intravaginally on Day 6 of pregnancy while those in a second group were given blank tampons and 
those in a third group were hysterectomized under ether anaesthesia. The mean ovarian weights were determined at autopsy on Day 15.

In a second experiment, eight rats were ovariectomized on Day 7 , and a further group of eight were ovariectomized and given progesterone implants on Days 7,10 and 13. Two similar groups of eight animals were given 5HT on Day 7 or $5 \mathrm{HT}$ followed by progesterone implants. Control rats were given blank tampons. All the rats were killed on Day 16 of pregnancy and the contents of their uteri were examined. Ovarian weights of the intact animals were determined.

\section{Systemic effects: gastrointestinal motility}

Fifty mature female rats were fasted for $24 \mathrm{hr}$ before a suspension of charcoal in an aqueous medium containing $1.2 \%$ carboxymethyl cellulose and $1.5 \%$ Tween 80 was given orally. The dose of charcoal was $100 \mathrm{mg} / \mathrm{kg}$ body weight and the dose volume was adjusted to $25 \mathrm{ml} / \mathrm{kg}$. Twenty-five of the rats were also given $10 \mathrm{mg} 5 \mathrm{HT}$ at the same time as the charcoal suspension, while the remainder received blank tampons.

Five animals from each group were killed 15 min after treatment. A further five animals from each group were killed after $30 \mathrm{~min}$ and similarly after 1,2 and $4 \mathrm{hr}$. At autopsy, the intestines were removed entire, and dissected free of the mesentery. The total intestinal length was measured and the mid-point of the charcoal mass was recorded. This mid-point value was taken as the position of the charcoal and was expressed as a percentage of the entire intestinal length traversed. The mean percentage traversed at the various times were calculated for the test and control groups and compared statistically. This method is similar to that used by Pala, Coppi \& Crescenzi (1966).

\section{RESULTS}

\section{Antifertility activity of $5 H T$}

The results summarized in Table 1 show that intravaginal administration of $5 \mathrm{HT}$ terminated pregnancy in all animals when $10 \mathrm{mg}$ were given on Days 6 , 7 or 8 but was not completely effective if given on Days 4 or 5 . A dose of $5 \mathrm{mg}$ on Days 6,7 or 8 failed to produce complete antifertility effects but reduced fertility to a similar level in each case.

A period of exposure greater than $2 \mathrm{hr}$ and less than $4 \mathrm{hr}$ was required for

Table 1. Mean percentage of viable fetuses in rats at autopsy after intravaginal administration of $5 \mathrm{HT}$ on various days of pregnancy

\begin{tabular}{cccccc}
\hline $\begin{array}{c}\text { Dose of } 5 H T \\
(\mathrm{mg})^{*}\end{array}$ & \multicolumn{4}{c}{ Day of pregnancy $5 H T$ given } \\
\cline { 2 - 6 } & 4 & \multicolumn{1}{c}{5} & \multicolumn{1}{c}{6} & \multicolumn{1}{c}{7} & \multicolumn{1}{c}{8} \\
\hline 10 & 60 & 59 & 0 & 0 & 0 \\
5 & 100 & 100 & 95 & 97 & 56 \\
0 & & & & 99 \\
\hline
\end{tabular}

* Five rats/group. 
Table 2. Effect of 5HT on fertility and ovarian weight in rats after intravaginal administration of $10 \mathrm{mg}$ on Day 6 of pregnancy and subsequent removal

\begin{tabular}{|c|c|c|c|c|c|c|}
\hline \multirow{2}{*}{$\begin{array}{c}\text { Time tampon } \\
\text { in the } \\
\text { vagina } \\
(h r)\end{array}$} & \multicolumn{3}{|c|}{ Control rats } & \multicolumn{3}{|c|}{ Rats given $5 H T$} \\
\hline & $\begin{array}{c}\text { No. not } \\
\text { pregnant }\end{array}$ & $\begin{array}{l}\% \text { Viable } \\
\text { fetuses }\end{array}$ & $\begin{array}{c}\text { Mean ovarian } \\
\text { wt (mglpair) } \\
\quad \pm S . E . M .\end{array}$ & $\underset{\text { pregnant }}{\text { No. not }}$ & $\begin{array}{l}\% \text { Viable } \\
\text { fetuses }\end{array}$ & $\begin{array}{c}\text { Mean ovarian } \\
\text { wt (mg/pair) } \\
\pm \text { S.E.M. }\end{array}$ \\
\hline $\begin{array}{r}1 \\
2 \\
4 \\
8 \\
16 \\
32\end{array}$ & $\begin{array}{l}0 \\
0 \\
1 \\
1 \\
1 \\
0\end{array}$ & $\begin{array}{l}100 \\
100 \\
100 \\
100 \\
100 \\
100\end{array}$ & $\begin{array}{r}109 \cdot 0 \pm 2 \cdot 85 \\
85 \cdot 4 \pm 4 \cdot 51 \\
90 \cdot 4 \pm 3 \cdot 09 \\
88 \cdot 6 \pm 5 \cdot 66 \\
86 \cdot 4 \pm 7 \cdot 33 \\
97 \cdot 2 \pm 2 \cdot 23\end{array}$ & $\begin{array}{l}3 \\
3 \\
5 \\
5 \\
5 \\
5\end{array}$ & $\begin{array}{r}10 \\
27 \\
0 \\
0 \\
0 \\
0\end{array}$ & $\begin{array}{l}86.4 \pm 10 \cdot 63 \\
87.0 \pm 7.21 \\
76.2 \pm 5.32 \\
72.6 \pm 5.55 \\
76.6 \pm 6.06 \\
71.0 \pm 1.73\end{array}$ \\
\hline
\end{tabular}

There were five rats/group.

complete antifertility activity (Table 2 ). These results also show that complete antifertility activity was associated with a reduction in mean ovarian weight, while incomplete activity was not. The reduction in ovarian weight could be correlated visually with atrophy of the CL. Extraction and assay of the 5HT remaining on tampons after $4 \mathrm{hr}$ in the vagina showed that a mean of $6.0 \mathrm{mg} /$ rat had been absorbed. Variation however was considerable, the range of five replicates being 2.7 to $8.1 \mathrm{mg}$.

\section{Mechanism of antifertility activity}

Highly significant $(P<0.01)$ reductions in ovarian weight at autopsy were obtained whether pregnancy was terminated on Day 6 by administration of $5 \mathrm{HT}$ or by hysterectomy (Table 3 ).

Table 3. Effect of $10 \mathrm{mg} 5 \mathrm{HT}$ or hysterectomy of rats on Day 6 of pregnancy upon mean ovarian weights at autopsy

\begin{tabular}{lc}
\hline \multicolumn{1}{c}{ Treatment } & $\begin{array}{c}\text { Mean ovarian wt (mg/pair) } \\
\pm S . E . M .\end{array}$ \\
\hline 5HT & $77.5 \pm 4 \cdot 56^{*}$ \\
Hysterectomy & $72.9 \pm 2 \cdot 32^{*}$ \\
None & $103.9 \pm 2 \cdot 78$ \\
\hline
\end{tabular}

There were ten rats/group.

* Significantly different from control, $P<0.01$.

A schedule of progesterone implants administered every 3rd day maintained pregnancy in the ovariectomized rat (Table 4). Preliminary experiments have shown that a single implant at the time of ovariectomy was ineffective due to encapsulation of the implant. This schedule however was ineffective in maintaining pregnancy in animals treated with $5 \mathrm{HT}$.

\section{Systemic effects: gastrointestinal motility}

The results given in Table 5 show that intravaginal administration of $5 \mathrm{HT}$ 
Table 4. Effect of subcutaneous progesterone implants on the maintenance of pregnancy in rats ovariectomized or given $10 \mathrm{mg} 5 \mathrm{HT}$ on Day 7

\begin{tabular}{|c|c|c|c|}
\hline Treatment & No. pregnant & $\begin{array}{l}\% \text { Live } \\
\text { fetuses }\end{array}$ & $\begin{array}{l}\text { Mean ovarian } \\
\text { wt (mg/pair) } \\
\quad \pm \text { S.E.M. }\end{array}$ \\
\hline $\begin{array}{l}\text { Sham operation } \\
\text { Ovariectomy } \\
\text { Ovariectomy + progesterone on }\end{array}$ & $\begin{array}{l}8 \\
0\end{array}$ & $\begin{array}{r}88 \\
0\end{array}$ & $98 \cdot 5 \pm 3 \cdot 69$ \\
\hline $\begin{array}{l}\text { Days } 7,10 \text { and } 13 \\
\text { 5HT } 10 \mathrm{mg}\end{array}$ & $\begin{array}{l}8 \\
2\end{array}$ & $\begin{array}{r}51 \\
4\end{array}$ & $77 \cdot \overline{3 \pm 4 \cdot 70}$ \\
\hline $\begin{array}{l}\text { 5HT } 10 \mathrm{mg}+\text { progesterone on } \\
\text { Days } 7,10 \text { and } 13\end{array}$ & 3 & 11 & $69 \cdot 6 \pm 4 \cdot 93$ \\
\hline
\end{tabular}

There were eight rats/group.

Table 5. Effect of $10 \mathrm{mg} 5 \mathrm{HT}$ intravaginally on the proportion of the gastrointestinal tract traversed by a carbon meal in mature female rats

\begin{tabular}{lccccc}
\hline & \multicolumn{5}{c}{ Time of autopsy after dosing } \\
\cline { 2 - 6 } & $15 \mathrm{~min}$ & $30 \mathrm{~min}$ & $1 \mathrm{hr}$ & $2 \mathrm{hr}$ & $\mathbf{4} \mathrm{hr}$ \\
\hline 5HT $(10 \mathrm{mg} / \mathrm{rat})$ & $21 \cdot 6 \pm 0.84$ & $19 \cdot 3 \pm 2 \cdot 10$ & $19 \cdot 0 \pm 2 \cdot 68$ & $38 \cdot 8 \pm 5 \cdot 89$ & $62 \cdot 1 \pm 5 \cdot 31$ \\
Control & $39 \cdot 7 \pm 4 \cdot 28$ & $47 \cdot 4 \pm 3 \cdot 41$ & $49 \cdot 6 \pm 2 \cdot 57$ & $68 \cdot 5 \pm 3 \cdot 11$ & $72 \cdot 1 \pm 6 \cdot 17$ \\
\hline Difference & $P<0.05$ & $P<0.02$ & $P<0.05$ & $P<0.05$ & N.S. \\
\hline
\end{tabular}

Values expressed as mean $\%$ of tract traversed \pm S.E.M.

significantly reduced the length of the intestine traversed by a carbon meal for a period of $2 \mathrm{hr}$. The effect was significant after $15 \mathrm{~min}$ and recovery experiments indicated that a mean of $2.2 \mathrm{mg} 5 \mathrm{HT}$ (range $1 \cdot 1$ to 3.7 ) was absorbed in a 15min period.

\section{DISCUSSION}

During pregnancy in the rat, an increase in ovarian weight occurs between Days 12 and 17 which correlates with an increase in luteal size. The ovarian weights on or after Day 15 therefore are a convenient numerical index of luteal growth or regression. Dosage with $5 \mathrm{H}^{\mathrm{T}} \mathrm{T}$ is shown to be effective in terminating pregnancy in the rat following intravaginal administration on Days 6,7 or 8, sensitivity being approximately the same on each of these 3 days. Complete antifertility activity is obtained provided that the intravaginal tampons are left in place for $4 \mathrm{hr}$ and this is associated with a significant reduction in ovarian weight. These data do not, however, indicate whether luteolysis is the cause or the result of termination of pregnancy, since similar reductions in ovarian weight can be observed following hysterectomy. Since treatment for 1 and $2 \mathrm{hr}$ is shown to reduce the percentage of viable fetuses without affecting ovarian weight, it may be concluded that the luteolytic effects of 5HT are either a consequence of the antifertility effects or are independent of these effects. These 
conclusions are supported by the finding that a schedule of progesterone implants capable of replacing ovarian progesterone secretion in the maintenance of pregnancy did not prevent the antifertility effects of 5HT. Thus, it is concluded that these antifertility effects are not primarily due to lack of progesterone from the CL. This is further supported by the work of Marley (1974), who showed that the antifertility activity of $5 \mathrm{HT}$ may be reversed by dipyridamole and is therefore presumably a consequence of vasoconstriction. While both uterine and ovarian vasoconstriction may produce antifertility effects, the present study indicates that the antifertility effects are not mediated through the ovary. Luteolytic effects, however, may be due to ovarian vasoconstriction. Wilson \& McDonald (1974) have shown that the ovarian effects of 5HT in blocking ovulation can be reversed by dipyridamole, and are thus probably due to vasoconstriction. It is possible that luteolytic effects may be mediated by the same mechanism.

The results of this study indicate that administration of the minimal effective antifertility dose of $5 \mathrm{HT}$ by the intravaginal route produced significant effects on the gastrointestinal tract indicative of general systemic absorption (Table 5). The fact that inhibition, and not stimulation, of intestinal motility was recorded is not surprising in view of the complex effect of $5 \mathrm{HT}$ on the intestine (Douglass, 1970). This failure of local administration to limit the effects of the compound, and the high species specificity reported by Marley (1974), make it unlikely that the antifertility effects could ever be exploited for the control of human fertility.

\section{REFERENCES}

Douglass, W. W. (1970) Histamine and antihistamines; 5-hydroxytryptamine and antagonists. In The Pharmacological Basis of Therapeutics, 4th edn, pp. 621-622. Eds. L. S. Goodman and A. Gilman. Macmillan, London.

Lindsay, D., Poulson, E. \& Robson, J. M. (1963) The effect of 5-hydroxytryptamine on pregnancy. $\mathcal{F}$. Endocr. 26, 85-96.

MARLEY, P. B. (1969) Antifertility effect of 5-hydroxytryptamine at the time of implantation in mice and rats. F. Endocr. 43 , xxxiv.

Marley, P. B. (1974) Antifertility action of 5-hydroxytryptamine at the time of implantation: mechanism in the rat and action in the mouse, guinea-pig and rabbit. F. Reprod. Fert. 36, 267-274.

Marley, P. B., Robson, J. M. \& Sullivan, F. M. (1967) Embryotoxic and teratogenic action of 5hydroxytryptamine: mechanism of action in the rat. Br. F. Pharmac. 31, 494-505.

Pala, G., Coppi, G. \& Grescenzi, E. (1966) On the laxative properties of sulphuric esters of phenols, with particular reference to 4,4'-(2-picolylidene)-bis-phenylsulphuric acid disodium salt (Picosulfol). Arch. int. Pharmacodyn. 164, 356-369.

Wirson, G. \& MaDonald, P. G. (1974) Inhibitory effect of serotonin on ovulation in adult rats. $\mathcal{F}$. Endocr. 60, 253-260. 